\title{
Variation in Carbohydrate Reserves and Dry Matter Production of Bush Tea (Athrixia phylicoides) Grown under Different Environmental Conditions
}

\author{
Fhatuwani N. Mudau \\ Department of Agriculture and Animal Health, University of South Africa, \\ Private Bag X6, Florida 1710, South Africa
}

Ambani R. Mudau

Department of Life and Consumer Sciences, University of South Africa, Private Bag X6, Florida 1710, South Africa

\author{
Mpumelelo Nkomo \\ Department of Agriculture and Animal Health, University of South Africa, \\ Private Bag X6, Florida 1710, South Africa
}

Wonder Ngezimana

Department of Crop Science, Marondera College of Agricultural Sciences and Technology, University of Zimbabwe, P.O. Box 35, Marondera, Zimbabwe

Additional index words. seasonal pruning, pruning frequency, starch, sugar

\begin{abstract}
Reserve carbohydrates are critical for herbage yields, productivity as well as management strategies of bush tea (Athrixia phylicoides DC). This study was conducted to evaluate carbohydrate accumulation in response to pruning seasons (summer, autumn, winter, and spring) involving different organs grown under different conditions and to determine mean dry matter production of bush tea. Three separate parallel trials were conducted under wild, field, and glasshouse conditions. Seasons and different growing sites were considered as treatments. Treatments for all controlled trials (field and glasshouse) consisted of seasonal pruning (winter, spring, summer, and autumn). Trials were arranged using a randomized complete block design with 25 single plants as replicates per treatment. Seasonal responses revealed that winter had the highest starch $\left(145.0 \mathrm{mg} \cdot \mathrm{g}^{-1}\right)$ in the stems and reserve carbohydrates $\left(480.6 \mathrm{mg} \cdot \mathrm{g}^{-1}\right)$ in the roots, whereas in the roots sugar $\left(400.6 \mathrm{mg} \cdot \mathrm{g}^{-1}\right)$ was highest in summer. The highest significant root reserve carbohydrates occurred in winter $\left(594.6 \mathrm{mg} \cdot \mathrm{g}^{-1}\right)$ and the lowest in autumn (fall) (313.3 mg.g $\left.{ }^{-1}\right)$. Bush tea plants pruned during winter had the highest overall reserve carbohydrates in the stem $\left(598.7 \mathrm{mg} \cdot \mathrm{g}^{-1}\right)$. Under glasshouse conditions, the highest dry matter production was observed in December (midsummer) (170 g per plant); while in field-grown plants in the same month dry matter production was $400 \mathrm{~g}$ per plant. Therefore, the best time to maximize production of bush tea is during the spring and summer seasons.
\end{abstract}

Several studies have demonstrated that reserve carbohydrate levels in trees decrease considerably during periods of rapid growth (Demirtas et al., 2010). Reduced levels of reserve carbohydrates during regrowth have been reported for tea (Camellia sinensis) (Kandiah et al., 1984; Selvendran and Selvendran, 1972) and this is attributed to pruning frequency as standard practice during harvesting. It is generally hypothesized that plants mobilize reserve

Received for publication 19 July 2016. Accepted for publication 19 Oct. 2016.

We are grateful to the National Research Fund (NRF) for funding.

${ }^{1}$ Corresponding author. E-mail: mudaufn@unisa. ac.za. carbohydrates to rebuild photosynthetic tissue after cutting (Demirtas et al., 2010), defoliation (Teague and Smit, 1992), or seasonal loss of foliage (Latt et al., 2000). The authors further reported that soluble sugar concentrations in roots and stems were being maintained consistently at or above the levels in their control, suggesting that sugar levels were maintained through the hydrolysis of starch reserves, whereas no starch replenishment occurred shortly after pruning.

Besides genetic factors, plant physiological responses can vary due to cultural practices such as mineral nutrition (Mudau et al., 2006), harvesting practices (Maudu et al., 2010), and climatic factors during a growing season (Cui et al., 2013; Mudau et al., 2005). The seasonal variation has been reported by Mudau et al. (2007a) and can be ascribed to agronomic practices such as pruning (Maudu et al., 2010). Pruning removes substantial amounts of leaves and branches, resulting in a drastic reduction of photosynthesis products (Marasha et al., 2013). The ability of a bush tea plant to recover from pruning depends on the plant's starch reserves in the roots (Ndunguru 2004; Panda, 2011). Traditionally, the whole bush tea plant is harvested for medicinal and tea purposes (Maudu et al., 2010; Mudau et al., 2007b); hence the pruning treatments were synchronized as if pruning for tea harvest.

Pruning herbal tea plants is an intensive agronomic practice that affects productivity and quality (Marasha et al., 2013). Tea quality is inevitably related to phytochemical composition and indirectly influences the health benefits of herbal tea. Fluctuations in carbohydrate reserves are also thought to be directly influenced by pruning frequency (Latt et al., 2000), as regrowth of flush depends on the abundance of carbohydrates stored. The quality of tea is determined by pruning frequencies (Panda, 2011), and no studies on bush tea to date have investigated the seasonal variation of carbohydrate accumulation and dynamics as affected by pruning frequencies. Currently, there are small plantations of bush tea cultivation in South Africa and data are lacking, which elucidates the growth pattern and its effect on vegetative flush after pruning. The objectives of the study were a) to determine the response of sugar, starch, and total carbohydrate reserve in all four seasons; b) to investigate the influence of three growing environments (glasshouse, field condition, and wild bush tea) on the reserve carbohydrates allocation on roots, stem, and leaves; and c) to determine the influence of seasons on biomass/mean production of the bush tea.

\section{Materials and Methods}

\section{Study sites}

Wild bush tea. Wild bush tea materials were collected from Mudzidzidzi village in the Limpopo province of South Africa $\left(24^{\circ} 50^{\prime} \mathrm{S}, 31^{\circ} 17^{\prime} \mathrm{E}\right.$; altitude $610 \mathrm{~m}$ above mean sea level); with subtropical climate of summer rainfall, and cold and dry winters. The annual rainfall ranged from 600 to $800 \mathrm{~mm}$.

Glasshouse trial. A glasshouse trial was conducted at the University of South Africa Science Campus in Florida, South Africa. Temperatures in the glasshouse were kept between 20 and $24{ }^{\circ} \mathrm{C}$, with humidity at $60 \%$. The photosynthetically active radiation ranged from 134.38 to 157.24 units, whereas chlorophyll content ranged from 30.96 to 44.65 units. The planting materials made up of mature bush tea stock plants were collected from Mudzidzidzi village. Planting materials were selected on the basis of true to name and type, free of disease and insects, and in a healthy physiological state. During cultivation, to stimulate rapid and prolific rooting of cuttings, plants were cut about $7-8 \mathrm{~cm}$ long and were treated with Seradix No. $2[0.3 \%$ Indole-3-butric acid (IBA)] (Bayer ${ }^{\circledR}$ Pretoria, South Africa) and planted on seedling trays 
on a mist bed, supplied with a misting system operating through misting nozzles. The mist bed used was $3 \mathrm{~m}$ long, $1.5 \mathrm{~m}$ wide, and $0.5 \mathrm{~m}$ high. Light irrigation was done three times a day every day except on rainy days.

Bush tea seedlings were allowed to grow on seedlings trays for 3 months. Rooted cuttings (seedlings) were ready and were transplanted directly into $20-\mathrm{L}$ bags. The medium used during transplanting was pine bark and sand at a ratio of $2: 1$, respectively. In an attempt to achieve optimum growth, the growing bush tea plants in plastic bags were treated to a split application with $\mathrm{N}, \mathrm{P}$, and $\mathrm{K}$ at rates 300,300 , and $200 \mathrm{~kg} \cdot \mathrm{ha}^{-1}$, respectively, as reported by Mudau et al. (2007a) 2 weeks after transplanting and later transplanted to the field.

Field cultivated trial. The experiments on cultivated bush tea were carried out on Morgenzon commercial farm $\left(22^{\circ} 56^{\prime} 60 \mathrm{~S}\right.$, $30^{\circ} 28^{\prime} 60 \mathrm{E}$; altitude $709 \mathrm{~m}$; summer rainfall and dry winter). Planting materials were selected on the basis of true-to-type and name, free of disease and insects, and in a healthy physiological state. Meteorological data on temperature $\left({ }^{\circ} \mathrm{C}\right)$, rainfall $(\mathrm{mm})$, relative humidity $(\%)$, and evaporation $(\mathrm{mm})$ were supplied by the Agrometerological Division of the Department of Agriculture, Limpopo province (Table 1).

Plant material preparations. Plant materials were collected using methodology stated by Mudau et al. (2006). Plant material was then prepared as described in the glasshouse trial, the rooted cuttings were transplanted directly into the open fields.

\section{Treatments, design, and experimental details}

Trial 1. The seasonal effects on the response of root, stem, and leaf carbohydrate reserves of bush tea under field conditions.

The treatments consisted of bush tea cultivated in four seasons viz., autumn, winter, spring, and summer during the 2013/2014 seasons. The experiments started on 1 Mar. 2013 (beginning of autumn/fall) and ended on $28 \mathrm{Feb} .2014$ (end of summer). In each season, 50 single plants were planted in a randomized complete block design in the field.

Trial 2. Effects of growing environments on the partitioning of carbohydrates in the root, stem, and leaf of bush tea.

Treatments consisted of bush tea grown separately under glasshouse, field, and wild growing conditions. In the glasshouse and field conditions, 50 single bush tea plants were planted in a randomized complete block design. Thirty bush plants were used as replicates leaving buffer trees. In wild bush tea, 50 plants were randomly tagged.

Trial 3. Seasonal and cumulative dry matter production in bush tea under field conditions and in wild bush tea.

Table 1. Average seasonal variation in temperature, rainfall, relative humidity, and evaporation during growth of bush tea (2013-14) in Morgenzon commercial farm in the Limpopo province of South Africa.

\begin{tabular}{lcccc}
\hline Season & Avg temp $\left({ }^{\circ} \mathrm{C}\right)$ & Avg rainfall $(\mathrm{mm})$ & $\begin{array}{c}\text { Avg relative } \\
\text { humidity }(\%)\end{array}$ & Avg evaporation (mm) \\
\hline Autumn (fall) & 28 & 300 & 51 & 68 \\
Winter & 24 & 100 & 44 & 45 \\
Spring & 34 & 400 & 86 & 65 \\
Summer & 38 & 500 & 77 & 75 \\
\hline
\end{tabular}

Autumn (fall) (March, April, May); winter (June, July, August); spring (September, October, November); summer (December, January, February).

Field conditions. In each season, 50 single plants were planted in a randomized complete block design in the field during 2013 and 2014, respectively. Thirty bush plants were used as replicates leaving buffer trees. Thirty single bush plants were used as replicates leaving buffer trees.

Wild bush tea. Fifty single plants were randomly tagged.

Parameters recorded. At harvest, parameters recorded were soluble sugars (sucrose, glucose, and fructose), starch, and total reserve carbohydrates (the sum of sugar and starch). Samples were separated in plant organs as roots, stems, and leaves, and freeze dried for analyses.

\section{Sample preparation and carbohydrate analysis}

Carbohydrate analysis was conducted using a method described by Latt et al. (2000). Samples were analyzed using the perchloric acid/anthrone method to measure starch and soluble sugars (McCready et al., 1950; Yemm and Willis, 1954). The ethanol was used to extract soluble sugars from the ground samples and the washing was done four times. The supernatants of each sample were then kept in separate flasks to determine the sugar content. The remaining pellets (solid residues) were washed twice with $52 \%$ perchloric acid to solubilize the starch in the samples. The solubilized starch solutions were treated with a mixture of anthrone and sulfuric acid to hydrolyze the starch to glucose, producing a green color. Absorption was measured using a spectrophotometer at $620 \mathrm{~nm}$ wavelength; absorbances were regressed against readings from glucose standard solutions. A correlation factor of 0.9 was used in converting glucose equivalents to starch (McCready et al., 1950). Glucose content in the soluble sugar solution was determined by treatment with the anthrone/sulfuric acid mixture (Latt et al., 2000).

\section{Data collected and statistical analysis}

Data were subjected to analysis of variance using the general linear model of SAS version (version 9.2; SAS Institute, Cary, NC). Variables considered for roots, stems, and leaves included soluble sugar, starch, and total reserve carbohydrates (the sum of sugar and starch). Mean separations were done using Duncan multiple range test.

\section{Results}

Seasonal response of root carbohydrates allocations of bush tea. Results in Table 2 show that winter exhibited highest starch contents $\left(230.1 \mathrm{mg} \cdot \mathrm{g}^{-1}\right)$ followed by autumn (124.0 $\left.\mathrm{mg} \cdot \mathrm{g}^{-1}\right)$ compared with other seasons. The lowest starch contents were during spring $\left(85.0 \mathrm{mg} \cdot \mathrm{g}^{-1}\right)$. The range of highest and the lowest starch content was $147 \mathrm{mg} \cdot \mathrm{g}^{-1}$. The soluble highest soluble sugars content was in summer $\left(400.6 \mathrm{mg} \cdot \mathrm{g}^{-1}\right)$ with the lowest in autumn $\left(219.6 \mathrm{mg} \cdot \mathrm{g}^{-1}\right)$. The range between the highest and the lowest was $180.4 \mathrm{mg} \cdot \mathrm{g}^{-1}$ (Table 2). The highest reserve carbohydrates content was observed in winter $\left(550.8 \mathrm{mg} \cdot \mathrm{g}^{-1}\right)$, followed by summer, spring, and autumn (483.6 $\mathrm{mg} \cdot \mathrm{g}^{-1}, 433.3 \mathrm{mg} \cdot \mathrm{g}^{-1}$, and $343.6 \mathrm{mg} \cdot \mathrm{g}^{-1}$ ), respectively.

Seasonal response of stem carbohydrates allocations of bush tea. Table 2 shows the highest sugar content was observed in winter $\left(145.0 \mathrm{mg} \cdot \mathrm{g}^{-1}\right)$ and the lowest in summer (118.9 $\left.\mathrm{mg} \cdot \mathrm{g}^{-1}\right)$. The range between the lowest and the highest was $26.1 \mathrm{mg} \cdot \mathrm{g}^{-1}$. Winter had the highest soluble sugars content $\left(236.7 \mathrm{mg} \cdot \mathrm{g}^{-1}\right)$ followed by spring (231.9 $\left.\mathrm{mg} \cdot \mathrm{g}^{-1}\right)$ and the lowest contents were observed in summer and autumn (203.5 and $\left.203.0 \mathrm{mg} \cdot \mathrm{g}^{-1}\right)$, respectively (Table 2). The highest reserve carbohydrates content was during winter $\left(431.7 \mathrm{mg} \cdot \mathrm{g}^{-1}\right.$ ), followed by spring $\left(358.8 \mathrm{mg} \cdot \mathrm{g}^{-1}\right)$, with summer $\left(322.4 \mathrm{mg} \cdot \mathrm{g}^{-1}\right)$ and autumn having the lowest (335.9 $\mathrm{mg} \cdot \mathrm{g}^{-1}$ ) (Table 2).

Seasonal response of leaf carbohydrates allocations of bush tea. Table 2 demonstrated that winter had the lowest starch content of $201.0 \mathrm{mg} \cdot \mathrm{g}^{-1}$ in comparison with the other seasons. The range of starch content between the lowest and highest was $57.7 \mathrm{mg} \cdot \mathrm{g}^{-1}$. The highest soluble sugars content was observed in winter and summer $\left(279.6 \mathrm{mg} \cdot \mathrm{g}^{-1}\right.$ and $299.2 \mathrm{mg} \cdot \mathrm{g}^{-1}$ ), respectively, and followed by spring $\left(225.1 \mathrm{mg} \cdot \mathrm{g}^{-1}\right)$. However, the lowest soluble sugars content were during autumn $\left(188.9 \mathrm{mg} \cdot \mathrm{g}^{-1}\right)$. The range of soluble sugars was $110.3 \mathrm{mg} \cdot \mathrm{g}^{-1}$ (Table 2). Total reserve carbohydrates were highest during winter (480.6 $\left.\mathrm{mg} \cdot \mathrm{g}^{-1}\right)$ followed by summer (442.5 mg. $\left.\mathrm{g}^{-1}\right)$, spring (365.3 $\left.\mathrm{mg} \cdot \mathrm{g}^{-1}\right)$, and autumn (331.1 mg.g $\left.{ }^{-1}\right)$ (Table 2). There were no interactions between seasons and plant organs.

Response of partitioning of carbohydrates on the root, under different growing environments. Result in Table 3 show that growing seasons did not exhibit any significant differences in starch. Field conditions showed higher sugar contents $\left(130.5 \mathrm{mg} \cdot \mathrm{g}^{-1}\right)$ compared with glasshouse $\left(109.9 \mathrm{mg} \cdot \mathrm{g}^{-1}\right)$ and wild-growing plants (112.3 $\left.\mathrm{mg} \cdot \mathrm{g}^{-1}\right)$ (Table 3). The glasshouse exhibited the highest reserves (472.4 $\mathrm{mg} \cdot \mathrm{g}^{-1}$ ), 
Table 2. Effects of seasons on the allocation of carbohydrates on different organs of bush tea.

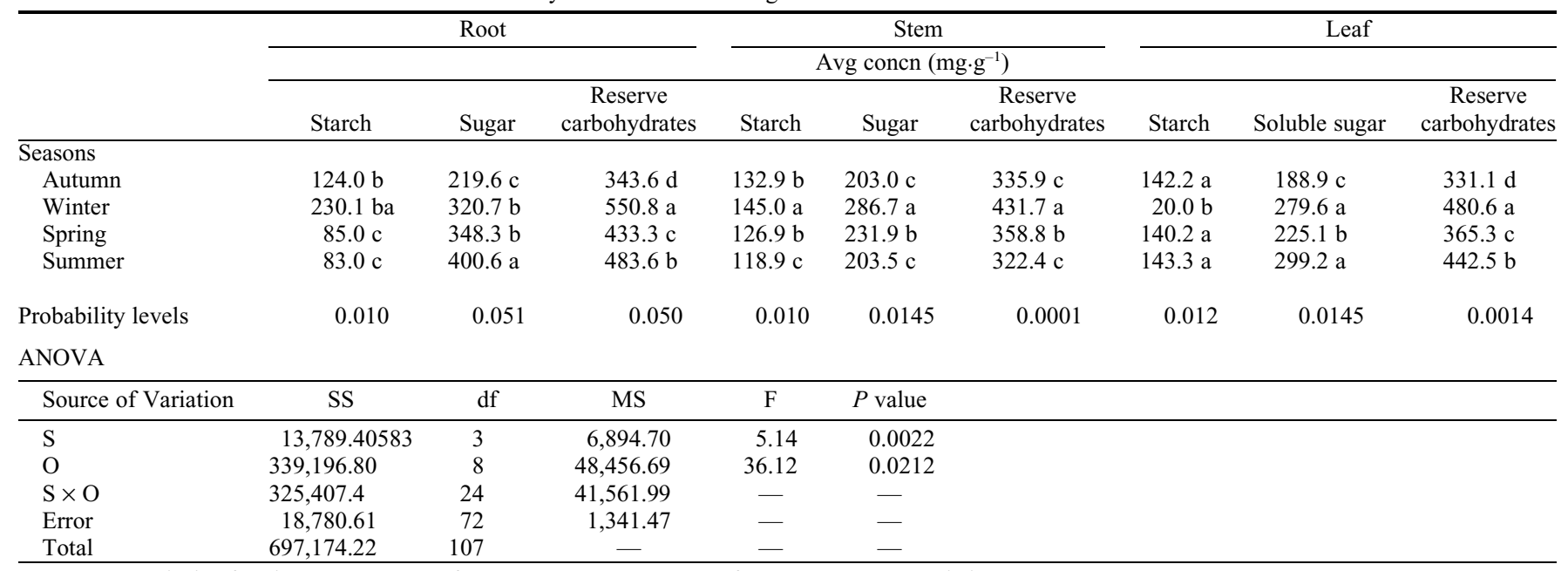

ANOVA = analysis of variance; $\mathrm{SS}=$ sum of squares; $\mathrm{MS}=$ mean sum of squares; $\mathrm{F}=$ test statistic; $\mathrm{S}=$ season; $\mathrm{O}=$ organ.

Means with the same letter are not significantly different using Duncan's multiple range test at the $5 \%$ level.

Table 3. Effects of growing environments on the partitioning of carbohydrates on the root, leaf, and stem.

\begin{tabular}{|c|c|c|c|c|c|c|c|c|c|}
\hline & \multicolumn{3}{|c|}{ Root } & \multicolumn{3}{|c|}{ Stem } & \multicolumn{3}{|c|}{ Leaf } \\
\hline & \multicolumn{9}{|c|}{ Avg concn $\left(\mathrm{mg} \cdot \mathrm{g}^{-1}\right)$} \\
\hline & Starch & Sugar & $\begin{array}{c}\text { Reserve } \\
\text { carbohydrates }\end{array}$ & Starch & Sugar & $\begin{array}{c}\text { Reserve } \\
\text { carbohydrates }\end{array}$ & Starch & Soluble sugar & $\begin{array}{c}\text { Reserve } \\
\text { carbohydrates }\end{array}$ \\
\hline Glasshouse & $362.5 \mathrm{a}$ & $109.9 \mathrm{~b}$ & $472.4 \mathrm{a}$ & $138.7 \mathrm{c}$ & $111.8 \mathrm{c}$ & $250.5 \mathrm{c}$ & $248.7 \mathrm{c}$ & $153.2 \mathrm{a}$ & $401.9 \mathrm{c}$ \\
\hline Field conditions & $322.3 \mathrm{a}$ & $130.5 \mathrm{a}$ & $452.8 \mathrm{~b}$ & $231.3 \mathrm{~b}$ & $130.9 \mathrm{~b}$ & $362.2 \mathrm{~b}$ & $277.2 \mathrm{a}$ & $156.7 \mathrm{a}$ & $433.9 \mathrm{a}$ \\
\hline Wild bush tea & $323.7 \mathrm{a}$ & $112.3 \mathrm{~b}$ & $436.0 \mathrm{c}$ & $320 \mathrm{a}$ & $140.3 \mathrm{a}$ & $460.3 \mathrm{a}$ & $263.8 \mathrm{~b}$ & $156.3 \mathrm{a}$ & $420.1 \mathrm{~b}$ \\
\hline \multicolumn{10}{|l|}{ ANOVA } \\
\hline Source of variation & SS & $\mathrm{df}$ & MS & $\mathrm{F}$ & $P$ value & & & & \\
\hline GS & $18,023.06$ & 2 & $18,023.06$ & 4.84 & 0.0270 & & & & \\
\hline $\mathrm{O}$ & $173,137.14$ & 8 & $24,733.88$ & 3.53 & 0.102 & & & & \\
\hline $\mathrm{GS} \times \mathrm{O}$ & $15,114.08$ & 16 & $31,161.25$ & & & & & & \\
\hline Error & $35,739.51$ & 7 & $5,105.64$ & & & & & & \\
\hline
\end{tabular}

ANOVA = analysis of variance; $\mathrm{SS}=$ sum of squares; $\mathrm{MS}=$ mean sum of squares; $\mathrm{F}=$ test statistic; $\mathrm{GS}=$ growing sites; $\mathrm{O}=$ organ.

Means with the same letter are not significantly different using Duncan's multiple range test at the $5 \%$ level.

followed by the field-grown plants $(452.8$ $\left.\mathrm{mg} \cdot \mathrm{g}^{-1}\right)$ and the lowest observed in the wild plants (436.0 $\mathrm{mg} \cdot \mathrm{g}^{-1}$ ) (Table 3 ).

Response of partitioning of carbohydrates on the leaves, under different growing environments. The highest content was recorded in the field $\left(277.2 \mathrm{mg} \cdot \mathrm{g}^{-1}\right)$, followed by the wild $\left(263.8 \mathrm{mg} \cdot \mathrm{g}^{-1}\right)$ and the lowest observed in the glasshouse (248.7 mg. ${ }^{-1}$ ) (Table 3). No significant differences in sugar content were observed in all growing conditions. The content of carbohydrates was higher in bush tea grown under field conditions $\left(433.9 \mathrm{mg} \cdot \mathrm{g}^{-1}\right)$, followed by bush tea from the wild (420.1 $\left.\mathrm{mg} \cdot \mathrm{g}^{-1}\right)$. The lowest total carbohydrates were in bush tea grown under glasshouse conditions (409.1 mg.g ${ }^{-1}$ ) (Table 3).

Response of partitioning of carbohydrates on the stem, under different growing environments. Starch content was highest in wild bush tea (320.0 mg. $\mathrm{g}^{-1}$ ), followed by bush tea grown under field conditions $\left(231.3 \mathrm{mg} \cdot \mathrm{g}^{-1}\right)$ and the lowest from bush tea grown under glasshouse conditions (138.7 mg. $\mathrm{g}^{-1}$ ) (Table 3 ). A similar trend as to what was observed in starch was seen with sugar content. Sugar content was highest in wild bush tea (140.3 $\left.\mathrm{mg} \cdot \mathrm{g}^{-1}\right)$, followed by bush tea grown under field conditions (130.9 $\left.\mathrm{mg} \cdot \mathrm{g}^{-1}\right)$ and the lowest from bush tea grown under glasshouse conditions (111.8 $\mathrm{mg} \cdot \mathrm{g}^{-1}$ ) (Table 3). The content of carbohydrates was higher in wild bush tea $\left(460.3 \mathrm{mg} \cdot \mathrm{g}^{-1}\right)$, followed by bush tea grown under field conditions $\left(362.2 \mathrm{mg} \cdot \mathrm{g}^{-1}\right)$. The lowest total carbohydrates were in bush tea grown under glasshouse conditions $\left(250.5 \mathrm{mg} \cdot \mathrm{g}^{-1}\right)$ (Table 3$)$. There was no interaction between growing sites and plant organs.

Seasonal and cumulative dry matter production in wild bush tea. Table 4 shows that autumn and winter had lower dry matter production compared with spring and summer. The highest production was being achieved in summer (400 g/tree), whereas in spring it ranged from 200 to $300 \mathrm{~g} /$ tree. The lowest values were observed in autumn and winter $(9 \mathrm{~g} /$ tree $)$. There was a distinct direct proportion between the number of cuts and mean production, as an increase in the number of cuts had higher mean dry matter production, with winter and autumn lower (one and four cuts, respectively) and the highest in summer (15 cuts) (Table 4).

Seasonal and cumulative dry matter production in field grown bush tea. Summer had the highest mean dry matter production ranging from 143.4 to $170.4 \mathrm{~g} /$ tree, followed by spring ( 46.9 to $90.4 \mathrm{~g} /$ tree), then autumn (30.8 to $49.1 \mathrm{~g} /$ tree) (Table 5). The lowest was recorded from the winter months ranging from 10 to $15 \mathrm{~g} /$ tree. Similarly, the lowest number of cuts was in winter (one and two cuts) and the highest obtained during summer ( 8 to 10 cuts). There was a strong correlation of $91 \%$ between number of cuts and mean production $\mathrm{g} /$ tree in cultivated bush tea, whereas the correlation of $75 \%$ was pronounced in the wild bush tea (Table 6).

\section{Discussion}

There is a clear difference in carbohydrate reserves between seasons, and different seasonal trends are observed with variable conditions (Hoffman et al., 2001). Plants generally have been known to have higher carbohydrate reserves in winter (Loescher et al., 1990; 
Table 4. Seasonal and cumulative dry matter production in wild bust tea.

\begin{tabular}{|c|c|c|c|}
\hline Seasons & Month & Number of cuts ${ }^{2}$ & Mean productions ${ }^{\mathrm{y}}(\mathrm{g} /$ tree $)$ \\
\hline \multirow{4}{*}{ Autumn } & March & 5 & $9.0 \mathrm{f}$ \\
\hline & April & 6 & $14.0 \mathrm{f}$ \\
\hline & May & 6 & $45.0 \mathrm{e}$ \\
\hline & June & 1 & $9.0 \mathrm{f}$ \\
\hline \multirow[t]{3}{*}{ Winter } & July & 2 & $10.0 \mathrm{f}$ \\
\hline & August & 3 & $80.0 \mathrm{~cd}$ \\
\hline & September & 6 & $200.4 \mathrm{c}$ \\
\hline \multirow[t]{3}{*}{ Spring } & October & 9 & $300.6 \mathrm{~b}$ \\
\hline & November & 10 & $200.4 \mathrm{c}$ \\
\hline & December & 14 & $400.1 \mathrm{a}$ \\
\hline \multirow[t]{2}{*}{ Summer } & January & 15 & $200.3 \mathrm{c}$ \\
\hline & February & 14 & $170.2 \mathrm{~d}$ \\
\hline
\end{tabular}

${ }^{\mathrm{z}}$ Number of cuts refers to the total number of times trees were pruned before the end date of sample data. ${ }^{\mathrm{y}}$ Means with the same letter are not significantly different using Duncan's multiple range test at the 5\% level.

Table 5. Seasonal and cumulative dry matter production in bush tea under field conditions.

\begin{tabular}{llcc}
\hline Seasons & Month & ${\text { Number of } \text { cuts }^{z}}^{z}$ & Mean production \\
\hline \multirow{2}{*}{ Autumn } & March $/$ tree $)$ \\
& April & 4 & $30.8 \mathrm{e}$ \\
& May & 4 & $40.9 \mathrm{~d}$ \\
\multirow{3}{*}{ Winter } & June & 4 & $49.1 \mathrm{~d}$ \\
& July & 1 & $10.0 \mathrm{f}$ \\
& August & 1 & $15.0 \mathrm{f}$ \\
Spring & September & 5 & $10.0 \mathrm{f}$ \\
& October & 3 & $46.9 \mathrm{~d}$ \\
& November & 7 & $89.4 \mathrm{c}$ \\
Summer & December & 8 & $90.4 \mathrm{c}$ \\
& January & 10 & $170.4 \mathrm{a}$ \\
& February & 10 & $143.4 \mathrm{~b}$ \\
\hline
\end{tabular}

${ }^{\mathrm{z}}$ Number of cuts refers to the total number of times trees were pruned before the end date of sample data ${ }^{\mathrm{y}}$ Means with the same letter are not significantly different using Duncan's multiple range test at the $5 \%$ level.

Table 6. Seasonal/monthly and cumulative dry matter production from day of planting to harvest of wild and cultivated bush tea.

\begin{tabular}{llclll}
\hline & \multicolumn{2}{c}{ Wild bush tea } & & \multicolumn{2}{c}{ Cultivated bush tea } \\
\cline { 2 - 3 } Correlation: & $\begin{array}{c}\text { Number of } \\
\text { cuts }^{z}\end{array}$ & Mean production g/tree & & $\begin{array}{c}\text { Number of } \\
\text { cuts }^{z}\end{array}$ & Mean production g/tree \\
\hline $\begin{array}{l}\text { Number of cuts } \\
\begin{array}{l}\text { Mean production } \\
\text { g/tree }\end{array}\end{array}$ & 1 & 1 & & 0.91 & 1 \\
\hline
\end{tabular}

${ }^{\mathrm{z}}$ Number of cuts refers to the total number of times trees were pruned before the end date of sample data.

White, 1973), and similar results were evident in this study. Previous studies suggest that the rate of photosynthesis in winter is reduced in comparison with that of other seasons, particularly summer and spring (Athanasiou et al., 2010). During winter plants tend to store most of the photosynthetic products for rapid recovery during favorable/flourishing seasons. The results show this particular trend in the abundance of carbohydrate reserves in the winter pruning at all the different plant locations wild, field condition, and greenhouse plants. Highest reserves of carbohydrates were found at the end of the winter, and this is in line with the sourcesink principle as explained by Morgenthal et al. (2006). The authors reported that the most reserves across the seasons are found in the roots (sink) with moderate to the same amounts in stems and leaves for greenhouse and field condition plants, whereas the wild plants had the least amounts in the stem and moderate quantities in the leaves (Ahmad et al., 2014).

Pruning has been reported to have an effect on the quality of tea, with the time and frequency of pruning being standard commercial practice (Ahmad et al., 2014; Ravichandran 2004). Compared with the unpruned plants, in the undomesticated bush tea plants, autumn and winter pruned plants produce higher quantities of both starch and sugar in relation to the spring and summer pruned plants, with plants pruned in winter having the most and those pruned in spring showing the least. The spring pruned plants had the lowest carbohydrate reserves and this was attributed to the higher pruning frequency. Thus, led to lower carbohydrates reserved meant for replenishment of the plant.

Pruning is known to encourage growth, and thus increased photosynthetic rate to provide energy for the new plant flush (Kaur et al., 2014). However, the greenhouse and field-grown plants pruned in all seasons had more overall carbohydrate reserves than unpruned plants, as expected. The winter pruned plants had the highest overall carbohydrate reserves, with the lowest being in autumn pruning instead of the spring pruning, as was seen in the natural-growing bush tea plants. This could be attributed to the fact that undomesticated growing plants will tend to experience harsher conditions and noncontinuous water supply compared with field condition and greenhouse plants.

As expected with an increase in pruning frequency, there is a direct increase in flush growth and carbohydrate increase as the photosynthetic rate is increased. With lesser pruning in winter as plants are in a dormant stage, there is a lower photosynthetic rate. Similar results were reported in Camellia sinensis by Ahmad et al. (2014), who reported that higher shoot density and shoot growth were associated with top pruning of tea during December and January produced the highest production of fresh leaves in black tea in the southern hemisphere. A gradual increase in flush growth and carbohydrates is observed from winter to the summer pruning season. When comparing field-grown plants to greenhouse plants, cumulative production of dry matter is higher in the field-grown plants. This could be attributed to the number of prunings, as field-grown plants could be pruned more frequently. Under greenhouse conditions the highest dry matter production was observed in December at $170 \mathrm{~g}$ per plant, whereas in field-grown plants in the same month $400 \mathrm{~g}$ per plant of dry matter was produced, a marked double-fold difference. This reveals a much higher growth rate with an increased number of prunings.

In conclusion, accumulation of carbohydrate reserves in different parts of the plant vary with seasons, and different seasonal trends are observed with variable conditions. Similar findings were observed in bush tea plants grown under glasshouse conditions and in the field conditions, with wild bush tea plants showing slightly different responses. Winter pruning has the highest overall carbohydrate reserves, with the least number of pruning and the least dry matter. Field-grown plants produce the most dry matter content and similar overall carbohydrate reserve abundance to greenhouse plants, thus field-grown plants produce the optimal dry matter and carbohydrate reserve conditions. The optimal time to maximize production of bush tea is during the spring and summer seasons since in autumn (fall) the plants are entering the dormancy stage.

\section{Literature Cited}

Ahmad, F., F.S. Hamid, S. Sarwar, A. Waheed, S Aslam, S. Islam, and I. Ali. 2014. Effect of different pruning times on the yield of tea (Camellia sinensis L.) under the climatic conditions of Mansehra-Pakistan. Sarhad J. Agr. 30:305-309.

Athanasiou, K., B.C. Dyson, R.E. Webster, and G.N. Johnson. 2010. Dynamic acclimation of photosynthesis increases plant fitness in changing environment. Plant Physiol. 152:366373.

Cui, G.T., W.X. Zhang, A. Zhang, H.B. Mu, H.J. Bai, J.Y. Duan, and C.Y. Wu. 2013. Variation in antioxidant activities of polysaccharides from Fructus jujubae in South Xinjiang area. Intl. J. Biol. Macromol. 57:278-284. 
Demirtas, N.M., I. Bolat, S. Ercisli, A. Ikinci, H. Olmez, M. Sahin, and B. Celik. 2010. The effects of different pruning treatments on seasonal variation of carbohydrates in 'Hacihaliloglu' apricot cultivar. Not. Bot. Hort. Agrobot. Cluj. 38:223-225.

Hoffman, R.M., J.A. Wilson, D.S. Kronfeld, W.L. Cooper, L.A. Lawrence, D. Sklan, and P.A. Harris. 2001. Hydrolyzable carbohydrates in pasture, hay, and horse feeds: Direct assay and seasonal variation. J. Anim. Sci. 79:500506.

Kandiah, S., D.T. Wettasinghe, and G. Wadasinghe. 1984. Root influence on shoot development in tea (Camellia sinensis (L.) O. Kuntze) following shoot pruning. J. Hort. Sci. 59:581587.

Kaur, L., S. Jayasekera, and P.J. Moughan. 2014. Processing and impact on antioxidants in beverages: Antioxidant quality of tea (Camellia sinensis) as affected by environmental factors. 22 May 2015. <http://hyperionacademy. com/wp-content/uploads/2014/05/3-s2.0B978012404738900013X-main.pdf>.

Latt, C.R., P.K.R. Nair, and B.T. Kang. 2000. Interactions among cutting frequency, reserve carbohydrates, and post-cutting biomass production in Gliricidia sepium and Leucaena leucocephala. Agrofor. Syst. 50:27-46.

Loescher, W.H., T. McCamant, and J.D. Keller. 1990. Carbohydrate reserves, translocation, and storage in woody plant roots. HortScience 25:274-281.
Marasha, N., I.K. Mariga, W. Ngezimana, and F.N. Mudau. 2013. Effect of pruning on carbohydrate dynamics of herbal and medicinal plant species: Prospects leading to research on the influence of pruning on productivity and biochemical composition of bush tea (Athrixia phylicoides DC.). Afr. J. Agr. Res. 8:35283533.

Maudu, M., F.N. Mudau, and I.K. Mariga. 2010. The effect of pruning on growth and chemical composition of cultivated bush tea (Athrixia phylicoides DC.). J. Med. Plants Res. 4:23532358.

McCready, R.M., J. Guggolz, V. Silviera, and H.S. Owens. 1950. Determination of starch and amylose in vegetables. Anal. Chem. 22:11561158.

Morgenthal, K., W. Weckwerth, and R. Steuer. 2006. Metabolomic networks in plants: Transitions from pattern recognition to biological interpretation. Biosystems 83:108-117.

Mudau, F.N., P. Soundy, and E.S. du Toit. 2005. Plant growth development of bush tea as affected by nitrogen, phosphorus, and potassium nutrition. HortScience 40:1896-1901.

Mudau, F.N., P. Soundy, and E.S. du Toit. 2007a. Effects of nitrogen, phosphorus, and potassium nutrition on total polyphenol content of bush tea (Athrixia phylicoides L.) leaves in shaded nursery environment. HortScience 42:334-338.

Mudau, F.N., P. Soundy, and E.S. du Toit. 2007b. Nitrogen, phosphorus, and potassium nutrition increases growth and total polyphenol concentrations of bush tea in a shaded nursery environment. HortTechnology 17:107-110.

Mudau, F.N., P. Soundy, E.S. du Toit, and J. Olivier. 2006. Variation in polyphenolic content of Athrixia phylicoides (L.) (Bush tea) leaves with season and nitrogen application. S. Afr. J. Bot. 72:398-402.

Ndunguru, B.J. 2004. Tea pruning and tipping. Module 6. Tea Research Institute of Tanzania. 18 May 2015. <http://www.trit.or.tz/Training\% 20modules/MODULE\%20No.\%206\%20Pruning. pdf $>$.

Panda, H. 2011. The complete book on cultivation and manufacture of tea. Asia Pacific Business Press Inc., New Delhi, India.

Ravichandran, R. 2004. The impact of pruning and time from pruning on quality and aroma constituents of black tea. Food Chem. 84:7-11.

SAS Institute. 2014. SAS/STAT user's guide. SAS Institute Inc., Cary, NC.

Selvendran, R.R. and S. Selvendran. 1972. Changes in the polysaccharides of the tea plant during post-prune growth. Phytochemistry 11 : $3167-3171$

Teague, W.R. and G.N. Smit. 1992. Relations between woody and herbaceous components and the effects of bush-clearing in southern African savannas. J. Grassl Soc South Afr. 9:60-71.

White, M.L. 1973. Carbohydrate reserves of grasses: A review. J. Range Manage. 26:13-18.

Yemm, E.W. and A.J. Willis. 1954. The estimation of carbohydrates in plant extracts by anthrone. Biochem. J. 57:508-514. 